\title{
泌尿器科における術後の細菌尿の英堵
}

\author{
神代 昭, 内山純子*1a, 広中 弘*1b \\ 山口大学医学部付属病院薬郕部*1a \\ 山口大学医学部泌尿器科*1b
}

\section{Bacteriuria after Operation in the Department of Urology}

\author{
AKIRA KOSHIRo, JUNKo UChIYAMA*1a, and HIROSHI HIRONAKA*1b \\ Department of Pharmacy, Yamaguchi University Hospital ${ }^{* 1 a}$ \\ Department of Urology, Yamaguchi University School of Medicine*1b
}

(Received January 28, 1980)

\begin{abstract}
To clarify the actual condition of bacteruria after operation, statistical analysis was carried out on bacteriuria in 333 inpatients in the department of urology of Yamaguchi University Hospital. The number of the strains isolated from the urine of all the patients during the 4 years from 1975 showed a decreasing tendency, but Serratia and Pseudomonas aeruginosa continued to be observed in many patients. In benign diseases, the postoperative bacteriuria was apparently correlated, respectively, to the period of indwelling catheterization, presence of bacteriuria before operation, age and the combined treatment of $\beta$-lactam antibiotics with aminoglycosides. In malignant cases, the correlation was observed only to the 2 former factors above mentioned. The correlation between bacteriuria and the operation procedure was not confirmed from the sample size in this analysis.
\end{abstract}

クラム陰性桿菌は院内感染の主要な起炎菌として知ら れ，特に近年はSerratia, Pseudomonasなど抗生剂に低 感受性の弱毒菌による感染症の增加が大きな問題となっ ている1).

われわれはさきに，当院に勤務する職員の手から分離 された Klebsiellaの各種抗生剤に対する感受性について 検討し，その MIC が入院患者から分離された Klebsiella の MIC と酷似していることから, 院内感染発生の可能 性が浱いことを報告しだ)。そこで今回はグラム陰性桿 菌による感染症の実態を理解し, 院内環境衛生の改善へ の示唆を得るため, 当院泌尿器科のカルテから手術後患 者における細菌尿の発現と，これに関係があると思われ る種々の因子について統計的解析を試み, 若干の知見を 得たので報告する.

\section{实閐方法}

1977 年, 1978 年の 2 年間における泌尿器科入院患者 333名のカルテから, 以下(1) (8)の各項について調査を行

*1a,b 宇部市小电 $1144: 1144$, Kogushi, Ube-shi, Yamaguchi, 755 Japan
った．ただし(1)については1975～1978年の 4 年間に括け る患者尿の分離菌について調査し，(3)（8)については細 菌尿（本報で細菌とはグラム陰性桿菌を意味し, 以下菌 と略す）の発現との関係を $\chi^{2}$ 検定, $\mathrm{t}$ 検定を用いて検 定した。な細菌尿は, 尿中白血球陽性 (10/HPF 以上) および尿培養陽性 $\left(10^{5} / \mathrm{ml}\right.$ 以上 $\left.{ }^{3}\right)$ をるって判定した.

（1）尿路分離菌の年次変遷

(2) 手術の部位別頻度

(3) カテーテル留固期間

(4) 術前の細菌尿と術後の感染期間

(5) カテーテル留圆患者の年令

(6) 手術様式

（7）抗生剂, 消毒剤の使用量

(8) 抗生剂の効果

(9) 手術前, 後の末梢血リンパ球数

\section{結}

\section{1. 尿路分淮菌の年次変迹}

1975１978年までの 4 年間の変遷をFig. 1 に示した. Serratia は検出全株の約 $30 \%$ を占めており，E. coli 10 
\%,Pr.morganii $5 \%$ といずれもほぼ一定の割合で発現 していた.P. aeruginosa は1976年に5\%まで減少した が, 以後增加し，1978 年には再び $20 \%$ 近くにまで達し た. Klebsiella は最近 3 年間約 $5 \%$ と変わらない. Enterobacter は 1976年以来減少して 1978年には $5 \%$ となり， Acinetobacter は $10 \%$ 前後において隔年に增減を繰り返 している.

\section{2. 手術の部位别頻度}

手術部位を解剖学的に上部 (腎, 尿管)，下部(膀脱, 前立腺，尿道，その他に大別し，各部位ごとに良性， 悪性疾患に分類した。Fig. 2 に示すように良性について は腎の $23 \%$ (77名)，前立腺の15\% (51名)，その他 $18 \%$ （61名）が多く，悪性については膀胱の 17\%（58名）が 圧倒的に多かった。

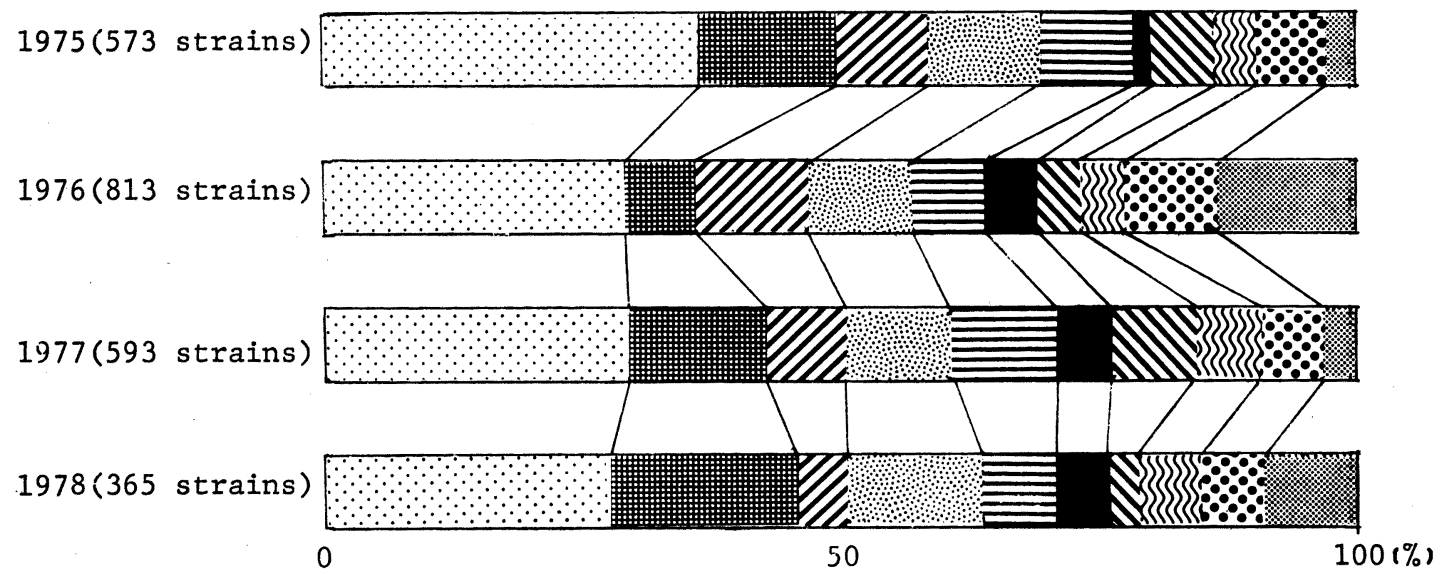

Fig. 1. Isolated Strains in Urinary Tract Infections

$\because \because$ Serratia

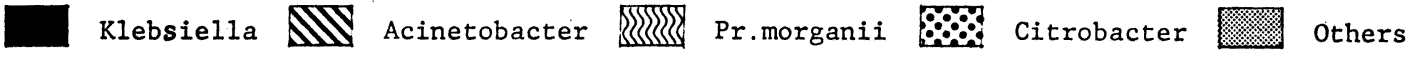

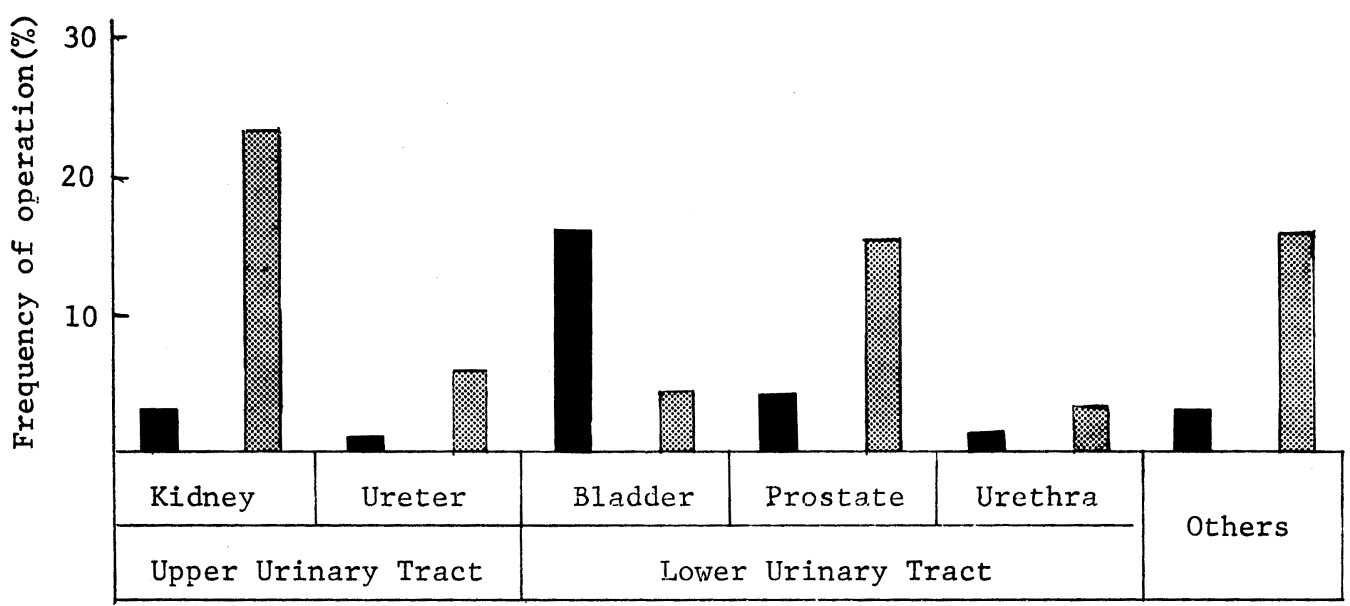

Fig. 2. Classification of Operative Regions in 333 Patients 


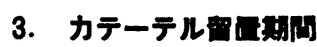

カテーテルの留置期間を 7 日以内と 8 日以上に分けて 比較すると, 細菌尿は留直 8 日以上に明らかに多かった $\left(\chi^{2}=8.39, \mathrm{P}<0.01\right)$ (Table 1). 菌を Serratia のみに 限定しその発現の有無で分類した場合も，カテーテル留 固 8 日以上が 7 日以内に比し明らかに多かった $\left(\chi^{2}=\right.$ 14.3, $\mathrm{P}<0.01$ ) (Table 2).

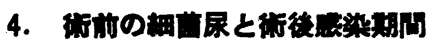

術前に細菌尿陽性と陰性の患者について, 術後の尿路 感染期間を比較した (Table 3). 細菌尿陽性では感染期 間が 15 日以上，また陰性では 14 日以内が明らかに多か った $\left(\chi^{2}=16.36, P<0.01\right)$. 次に良性疾患では 14 日以 内, 悪性疾患では15 日以上が明らかに多かった $\left(\chi^{2}=\right.$ 8.08, $\mathrm{P}<0.01$ ) (Table 4).

Table 1. Correlation between Bacteruria and Period of Catheterization

\begin{tabular}{cccc}
\hline \hline & \multicolumn{2}{c}{ Period of Catheterization } & Total \\
Bacteruria & 7 days $\geqq$ & 8 days $\leqq$ & 74 \\
\hline+ & 26 & 48 & 56 \\
\hline & 34 & 22 &
\end{tabular}

Table 2. Correlation between Appearance of Serratia in Bacteruria and Period of Catheterization

\begin{tabular}{cccc}
\hline \hline Serratia & Period of Catheterization & Total \\
& 7 days $\geqq$ & 8 days $\leqq$ & \\
\hline+ & 36 & 57 & 93 \\
- & 48 & 22 & 70 \\
\hline
\end{tabular}

$\times 2=14.3, P<0.01$

Table 3. Correlation between Bacteruria before Operation and Infections Period after Operation

\begin{tabular}{cccc}
\hline \hline $\begin{array}{c}\text { Preoperative } \\
\text { Bacteruria }\end{array}$ & Disappearance of & Bacteruria & Total \\
\hline+ & 14 days $\geqq$ & 15 days $\leqq$ & \\
\hline- & 30 & 56 & 86 \\
\hline
\end{tabular}

$X^{2}=16.36, P<0.01$ 
Table 4. Correlation between Diseases and Bacteruria after Operation

\begin{tabular}{cccc}
\hline Disease & Disappearance of Bacteruria & Total \\
& 14 days $\geqq$ & 15 days $\leqq$ & \\
\hline Benign & 74 & 53 & 127 \\
Malignant & 19 & 35 & 54 \\
\hline
\end{tabular}

$x^{2}=8.08, P<0.01$

\section{5. カテーテル留固意者の年令}

カテーテル留置患者の 細菌尿と 年令の 関係を 調査し た. 良性疾患 (Table 5-1) では 60 藏以上が 59 歳以下
に比して明らかに細菌尿が多かったのに反して $\left(\chi^{2}=\right.$ $7.60, \mathrm{P}<0.01)$, 悪性疾患 (Table 5-2) では年令によ る差は認められなかった。

Table 5. Correlation between Age and Bacteruria in Patients with Indwelling Catheter

1. Benign Disease

\begin{tabular}{cccc}
\hline Age & \multicolumn{2}{c}{ Bacteruria } & \\
\hline $59 \leq$ & 33 & 28 & 61 \\
$60 \leq$ & 46 & 13 & 59 \\
\hline
\end{tabular}

$x^{2}=7.60, P<0.01$

\section{6. 手街粎式}

手術様式と術後の細菌尿について，前立腺を経尿道的 に切除する術式である Transurethra Resection of Prostate (TUR-P) と開腹術式である恥骨上式単純前 立腺摘除術 Suprapubic Simple Prostatectomy (SSP) を比較したところ，Table 6-1 に示すよらに細菌尿の発 現に差は認められなかった $\left(\chi^{2}=2.27\right)$.

また膀胱腫瘍を経尿道的に切除する Trasurethral Resection Bladder Tumor (TUR-Bt) と TUR-P との 比較に执いてす Table 6-2 に示すように両法の間には 差は認めなかった $\left(\chi^{2}=1.83\right)$.

\section{7. 抗生绪, 消都の傎用量}

1977年, 1978年の 2 年間, 泌尿器科において繁用され た抗生剤と消毒剤の使用量について調查した。その 結果入院患者 1 人当りの抗生剂使用量は変わらないが (Fig. 3)，消毒剤は全般的に使用量が增えている（Fig.

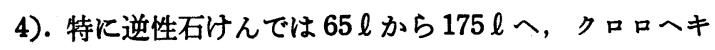

2. Malignant Disease

\begin{tabular}{cccc}
\hline & \multicolumn{3}{c}{ Bacteruria } \\
Age & + & - & Total \\
\hline $59 \geq$ & 12 & 3 & 15 \\
$60 \leqq$ & 33 & 6 & 39 \\
\hline
\end{tabular}

$\mathrm{P}=0.88$ by Fischer's Exact. Test

シシンテでは 120 lから 875 しと,それぞれ前年の 2.7 倍 および 7.3 倍に達していた. 次亜塩素酸ナトリウムる量 的には少ないが，前年比 15.6 倍の激增である.

\section{8. 抗生嵝の効果}

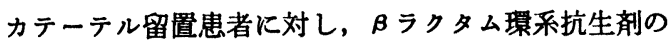
単独使用例と、これにアミノ配糖体系抗生剂を併用した 例と比較すると, Table 7-1 に示すように良性疾患にお いては単独使用例に細菌尿陽性が多く, 併用例に陰性が 多いことが明らかに認められた $\left(\chi^{2}=8.08, \mathrm{P}<0.01\right)$. しかし悪性疾患 (Table 7-2) では, 単独使用例と併用 使用例いずれの場合す細菌尿の発現には差を認めなかっ た $\left(\chi^{2}=3.13\right)$.

\section{9. 手街前，後の末格血リンパ球数}

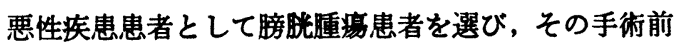
後に拉ける末梢血リン八球数の変化と細菌尿との関係を 調査した.すなわち Fig. 5 に示すよらに術後に細菌尿 陽性の患者は陰性の患者に比へ, 明らかに末梢血リンパ 


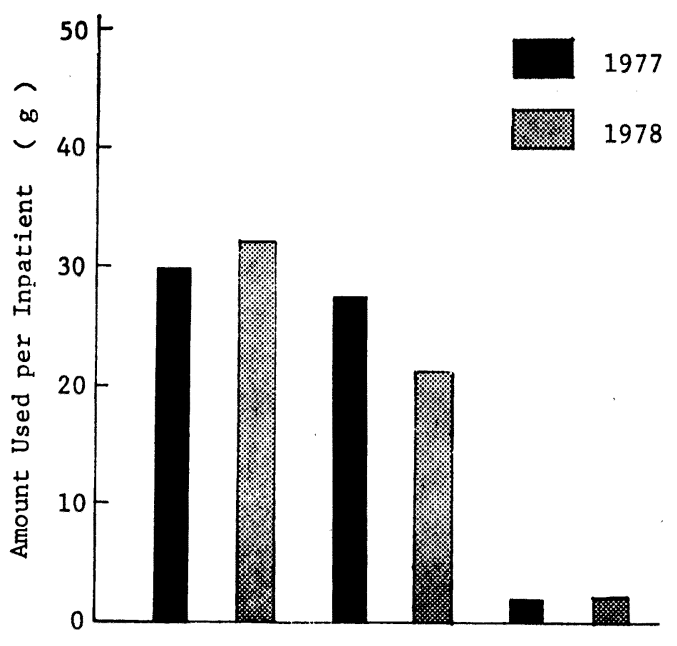

Penicillins Cepharosporins Aminoglycosides

Fig. 3. Average Amount of Antibiotics Used per Inpatient
球数の減少率が大きかった $(\mathrm{t}=2.73, \mathrm{P}<0.01)$.

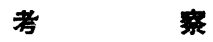

尿路感染の実態を理解するには，まず尿路からの分離 菌とその経年的变化を知っておく必要がある.1975年以 来 4 年間の尿路分離菌の変遷(Fig. 1)をみると, Serratia および Pseudomonas の 2 菌種のみで 40～50\% に達す る分布を示している.

一方，1960 年代に尿路感染症の主役を演じた E. coli は約 $10 \%$ を占めるに過ぎず，その他の菌種を含め尿路 分離菌の分布はこの 4 年間大きい変化をみせていない. 近年 Pseudomonas, Serratia などのいわゆる弱毒菌に よる院内感染症が大きな問題となっていることは周知の 事実であるが，本院も例外でないことがわかった.

カテーテルを尿道に留置した場合, 尿中に何らかの細 菌が検出されるのが常である．たとえば Serratia につ いて Maki'1c) らは菌の発現がカテーテル留置例に明らか に多いこと $(\mathrm{P}<0.029)$, MacArthur $5^{\mathrm{lh})}$ は Serratia の発現した 48 例中 37 例において，また那須ら

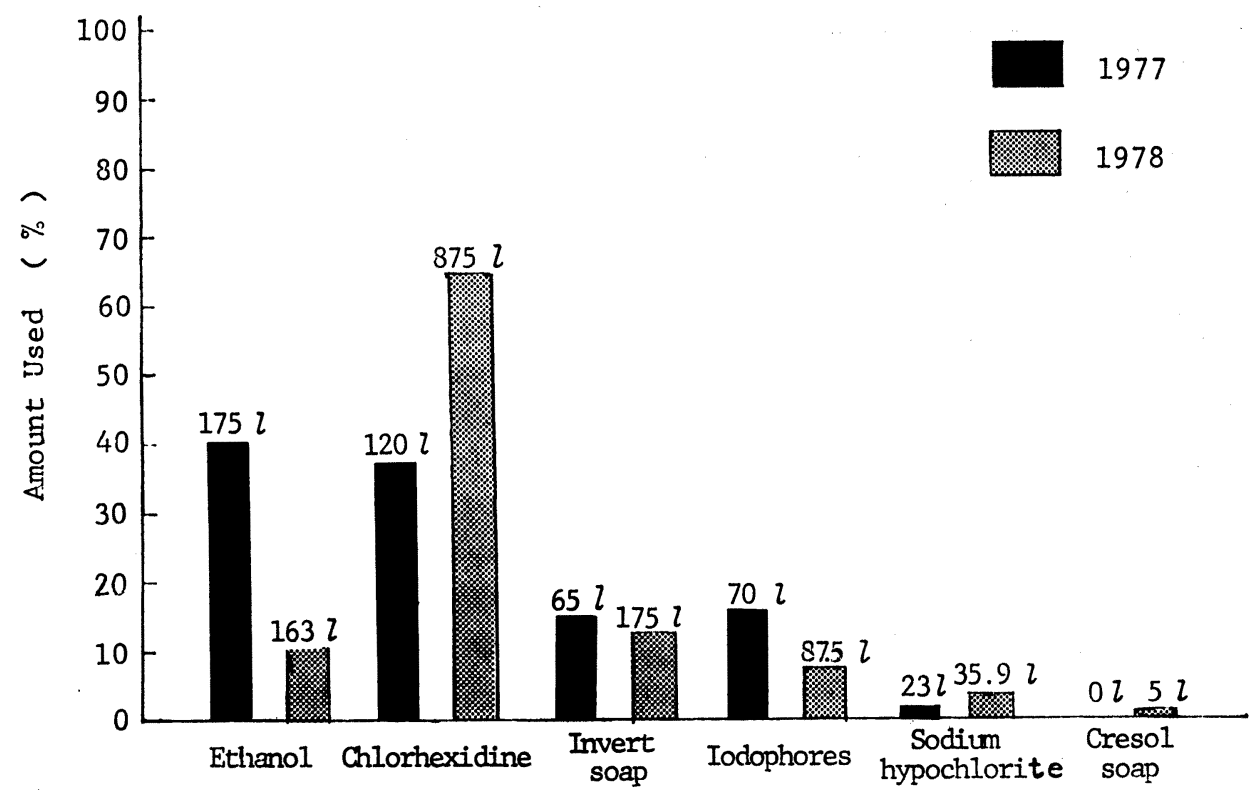

Fig. 4. Amount Used of Disinfectants

路生殖系の術後患者 25 例中 24 例に，それぞれ留置カテ 一テルが施行されていたと報告しており，カテーテル留 置で外界との交通が発生することによって細菌の逆行性 迷入を誘導することが明らかである. 今回の調査におい ても, カテーテル留置 7 日以内の患者に比へ 8 日以上の
患者では明らかに菌の発現が多く認められ (Table 1), 菌を Serratia のみに限定した場合す全く同様であった (Table 2). すなわち, カテーテル留置日数が 長期にわ たるほど細菌污染が確実に進行することがわかった。

熊沢ら ${ }^{1 e)}$ は細菌の 迷入点として外尿道口部, カテー 
Table 6. Correlation between Operation Procedure and Bacteruria

1.

\begin{tabular}{ccrc}
\hline \hline \multirow{2}{*}{ Bacteruria } & & & \\
Operation & Procedure \\
& TUR-P & SSP & Total \\
\hline+ & 12 & 14 & 26 \\
- & 18 & 9 & 27 \\
\hline
\end{tabular}

$x_{0.05}^{2}=2.27$, NS
2.

\begin{tabular}{|c|c|c|c|}
\hline Bacteruria & $\begin{array}{c}\text { Operation } \\
\text { TUR-Bt }\end{array}$ & $\begin{array}{c}\text { Procedure } \\
\text { TUR-P }\end{array}$ & Total \\
\hline+ & 22 & 12 & 34 \\
\hline- & 17 & 18 & 35 \\
\hline
\end{tabular}

$\times \stackrel{2}{0.05}=1.83$, NS

TUR-Bt : Transurethral Resection of Bladder Tumor

TUR-P : Transurethral Resection of Prostate

SSP : Suprapubic Simple Prostatectomy

Table 7. Correlation between Medicaton of Antibiotics and Bacteruria

1. Benign Disease

\begin{tabular}{cccc}
\hline \hline & \multicolumn{2}{c}{ Bacteruria } \\
Antibiotics & + & - & Total \\
\hline B - L & 38 & 22 & 60 \\
B-L + AGs & 7 & 17 & 24 \\
\hline \multicolumn{4}{c}{$X^{2}=8.08, P<0.01$}
\end{tabular}

$\beta$-L: $\beta$-Lactam Antibiotics

AGs : Aminoglycosides

テルと排尿チューブの接合点および排尿チューブと蓄尿 器の接合点の 3 カ所をあげ, 特に後二者からの細菌迷入 の危険について述べている.この点から蓄尿器とチュー ブを一体化し, 留直カテーテルとチューブ接合部を密閉 した市販の closed drainage system を使用することは 感染防止に有用といわれる1e,1h,4). 熊沢ら ${ }^{1 \mathrm{e})}$ とよれば, 従来法では留置して 2 日目にはすべて尿中から何らかの 細菌を検出したのに反し, 特別の配慮なしで $4 \sim 5$ 日間 は無菌状態を保ち得るという。

術前に細菌尿陽性であった患者は術後の感染期間が長 い(Table 3). このことは手術による尿路および術創の 侵意泇え術後のカテーテル留置が術前からの感染を助 長したためと考えられる. また悪性疾患の場合 (Table 4）には手術による侵摬もきわめて大きく, 感染防御能
2. Malignant Disease

\begin{tabular}{cccc}
\hline \hline & \multicolumn{2}{c}{ Bacteruria } \\
Antibiotics & + & - & Total \\
\hline$\beta-L$ & 13 & 19 & 32 \\
$\beta-\mathrm{L}+$ AGs & 6 & 6 & 12 \\
\hline \multicolumn{4}{c}{$x^{2}=3.13$, NS }
\end{tabular}

の低下が著しいことから，感染が長びくことは当然考え られ調查結果からもこのことが裏付けられた。またカテ 一テル留置患者の年令と細菌尿との関係について，良性 疾患では高令者に細菌尿が多い(Table 5-1) のに反し， 悪性疾患では年令に関係なく多数の患者に菌の発現がみ られた（Table 5-2）ことす感染防御能の 低下を反映し たものと考える.

つぎに膀胱腫瘍の経尿道的切除術式（TUR-Bt）は, 膀胱を開いて腫場を摘出するいわゆる open 方式に比 べると, 術後における Pseudomonas の増加は認められ ず,また Proteus, Klebsiella の增加る著しく減少すると いう.この理由について熊沢ら ${ }^{10)}$ は, TUR-Bt は膀胱 内のみの手術であるため, 尿が浸出した湿った術創:が 膀胱の外に存在しないことが原因の一つに考えられると 


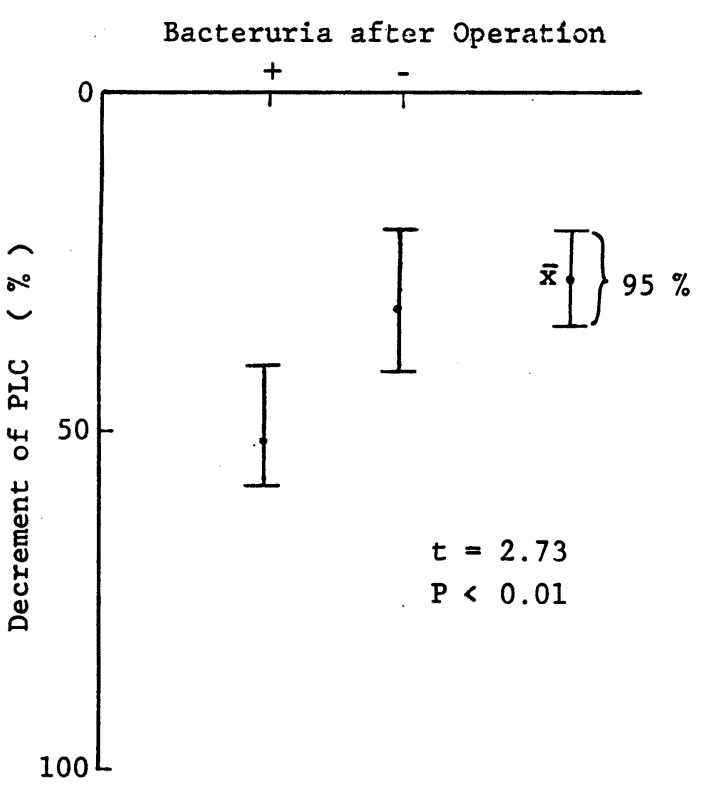

Fig. 5. Decrement of Peripheral Lymphocyte Count (PLC) in the Patients of Bladder Cancer after Operation

述べている. 今回われわれが調查したのは経尿道的前立 腺切除術式 (TUR-P) と open 方式である恥骨上式単純 性前立腺摘除術（SSP）であったが，これらの術式の間 には細菌尿の発現に関して差は認められなかった（Table 6-1). 摘除荿器が異なることもさることながら例数 の少ないことが差を検出し得なかった理由と思われる.

また同じ経尿道術式である TUR-Bt と TUR-P の間 にも細菌尿の 発現に差が認められなかった（Table 62). 前者は悪性疾患, 後者は良性疾患深適用例が多い. したがって個体の感染防御能から判定して TUR-Bt に 細菌尿が有意に多いと予想された。 しかし解析結果で は, TUR-Bt 飞細菌尿の多い傾向はみられるが $\chi^{\mathbf{3}}$ 検定 による差は認められなかった。 これる例数の不足による あのと考光る。

つぎに消毒剤使用量について述へる，泌尿器科病棟に 桝ける消毒剤の使用量（Fig. 4）をみると，1978年度は 前年度に比べクロロヘキシジンの使用量が 7.3 倍に激增 しているはか, 逆性石けんす 2.7 倍, その他の消毒郕す エタノールを除きすへて增加している. 特に 1977 年と 異なるところはクロロヘキシジンを消毒浏の主力として 使用し始めたことである. 病棟には膀腃洗浄用としてク 口ロヘキシジン液も供給しているが，本剤の使用量は前 年度とほとんど変わらなかったのでクロロヘキシジンの 增加は純粋に手洗い，器具など消毒用剤の增加を意味し
ているとこでこれら消毒剤使用量の激增した原因を調 查したところ，手洗い用消毒液の頻繁の取り替え，重症 患者の病室に手洗い設備を新設したことおよび病室の 清拭に新たに消毒剤を用い始めたことなどによることが わかった.これらの処置は院内感染防止の見地からきわ めて好ましい，Fig. 1 に明らかなように，1978年度に おける Strain 総数の著明な減少はこの処置の効果を旁 付けるものと考兄る.な打次亜塩素酸ナトリウムの急增 は. 1978 年度より病院内肝炎対策打合せ会で HB 抗原 消毒剤として採用されたためである.

最後に抗生剤の効果について考察を加える.グラム陰

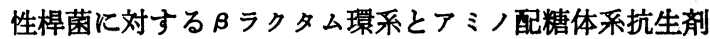

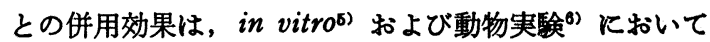
すでに認められており,臨床的にもPseudomonas, Klebsiella などを起炎菌とする 感染症に対する 効果が評価 されている7.

われわれは， $\boldsymbol{\beta}$ ラクタム環采抗生剂の単独投与とアミ ン配糖体系抗生剂との併用投与について細菌尿の有無に よってその効果を比較したところ，良性疾患においては 併用投与が明らかに細菌尿の発現が少なく効果がすぐれ ていることが認められた。しかし悪性疾患においては併 用の効果は認められず，また単独投与がすぐれていると むい党なかった (Table 7).ここです悪性疾患における 感染防御能の低下が抗生剤の併用の効果に関係している ことがわかる.

以上各因子ごとに考察したように，手術侵獎，術創の 侵襲, カテーテル留置による尿路の侵笠, 年令, 疾患の 良否が明らかに術後の細菌尿の発現に密接に関係してお り，その主要な原因は個体の感染防御能の低下であるこ とが強く推測された.このことは Fig. 5 に示すよらに, 術後の菌の発現した患者は菌の発現しない患者に比べ明 らかに末梢血リンパ球数の減少率が大きいという事実か らも裏付けられる。この観点からマウスに Picibanil@ を予め静注して P. aeruginosa, S. marcescens, C. albicans の感染を防止し得たとする野垣らの報告 ${ }^{8 \mathrm{a})}$ ，および マウスの肺炎球菌感染に 対する秋山らの同様な報告 $8 \mathrm{~b}$ は注目に値するすのである.

\section{結棆}

1975 1978年に至る 4 年間の当院泌尿器科患者の尿路 分離菌および1977年, 1978年の 2 年間の衍後尿路感染症 333 例について調查し次のような結果を得た。

（1） 1975年から 4 年間の尿路分離菌の変遷をみると， Strain の総数は1976 年以降減少の傾向を示したが, Serratia, P. aeruginosa の分離率は体然として高かっ 
た.

(2) カテーテル 8 日以上留置の患者は, 7 日以内の患 者に比べ細菌尿陽性者が明らかに多かった $(\mathrm{P}<0.01)$.

（3）術前に細菌尿陽性患者は術後の感染期間が明らか に長く，覀性疾患ではさらに顕著であった $(\mathrm{P}<0.01)$.

(4) カテーテル留置患者の年令と細菌尿については, 良性疾患患者では 59 煘以下に比べ 60 煘以上に細菌尿が 明らかに多く認められたが，悪性疾患患者では年令の老 若によらず圧倒的に細菌尿が発現した。

(5) 手術様式と菌の発現について今回の調查例では差 を認めなかった。

（6）消敨郕にいては前年に比しクロロヘキシジン， 逆性石けんの使用量が激增していた。

(7) Bラクタム環系抗生剂単独投与とアミノ配糖体系 抗生剂を併用投与した場合の 細菌尿の 発現を 比較する 之, 良性疾患では併用投与例に細菌尿の発現が明らかに 少なく $(P<0.01)$, 悪性疾患では併用, 単独いずれの場 合す差を認めなかった。

（8）膀胱腫暍患者の術後末梢血リンパ球数の減少率か 大きい患者は，減少率の小さい患者に比べて細菌尿が明 らかに多く認められた $(\mathrm{P}<0.01)$.

以上泌尿器科カルテから抽出した諸因子について尿中 細菌の発現を指標として統計解析を行い，術後尿路感染 の実態の若干を解明した。

胡辟 本稿をご校閲賜わった山口大学医学部泌尿器 科, 酒徳治三郎教授に深謝するとともに, 統計解析に助 言をいただいた池内信夫氏, カルテ調査に協力された薬 绪部研修生, 松沢 豊および事務員, 幸 敏子両氏の労 飞謝意を表します。
文

1) a) S.D.Allen, K.B.Conger : J. Urology, 101, 621 (1969) ; b) G. P. Bodey, V. Rodriguez, J. P. Smith : Cancer, 25, 199 (1970) ; c) D.G.Maki, C. G. Hennekens, C. W. Phillips, W.V. Shaw, J. V. Bennett : J. Infect. Dis., 128, 579 (1973) ; d) 清水曹八郎, 典住捷子, 人見照子, 長野百 合子, 千菜房子, 千葉純江, 大塚正和, 坂上ノリ 子；紷合略床，23，1694 (1974)；e）熊沢鿇一, 中车田誠一, 届藤秀明, 百瀬 俊郎: 最新医学, $30,402(1975)$; f) 那須 勝, 斎藤 厚, 提 恒雄, 岩永正明, 広田正毅 : 最新医学, 31, 1370 (1976)；g）川名林治，佐藤成大：医学のありみ 106, 841 (1978) ; h) B. S. MacArthar, N. B. Ackerman : Surg. Gynec. and Obst., 146, 49 (1978).

2）神代昭, 内山純子, 尾家重治, 羽島則子：日本 薬学会第98年会発表 (1978.4 岡山).

3) E. H. Kass : Arch. Internal. Med., 100, 709 (1957).

4) 西浦常雄: 日等誌, 15, 521 (1973).

5) J. Klastersky : Lancet, I, 654 (1971) ; J. Klastersky, B. Nyamubeya, L. Vandernborre : J.

Med. Microbiol., 7, 465 (1974) ; 中沢昭三, 大 梘雅子, 西野武志, 中尾雅文: Chemotherapy, 23，3201 (1975); 富岡 一, 小村芳夫 : Jap. J. Antibiotics, 29, 597 (1976).

6) V.T. Andriole : J.Infect. Dis., 129, 124 (1974).

7) C. B. Smith, P. E. Dans, J. N. Wilfent, M. Finland : J. Infect. Dis., 119, 370 (1969) ; S. Fykyn, I. phillips, M. Ridly : Lanect, I, 545 (1971) ; A. A. Carpenter, R. A. Seidel : J. Urol., 108, 192 (1972) ; J. Klastersky, C. Hensgens, F. mennier-Carpenter : J. Infect. Dis. (Suppl), 134, 433 (1976).

8） a）野垣兼朗：日本細菌学雑誌，34，667 (1979) ; b) 秋山武久, 山浦 昇, 大沢伸考, 江刺家幾 子：モダンメディア，23，315 (1977). 